European Journal of Education, Vol. 46, No. 2, 2011, Part II

\title{
Does Vocational Training Help Transition to Work? The 'New French Vocational Bachelor Degree’
}

\author{
Jean-François Giret
}

\section{Introduction}

The French higher education system witnessed a rapid expansion in student numbers in the last decades of the 20th century. Vocational courses developed in universities during this period amply benefited from this growth (Eicher, 1999). Representing only $4 \%$ of university students in 1970 , they accounted for $14.2 \%$ in 1998 and 23.8\% if we include medical students. Until the 1970s, the universities' vocational role was limited to training for the public service and a profession (teaching, medicine and law). The decrease in employment opportunities in the public service and the increase in enrolments in tertiary education forced universities to change their scope. Hence, the creation of vocational courses (university of technology diploma (DUT) in 1966, a master's degree in computer studies applied to management (MIAGE) in 1970, a higher specialised studies diploma (DESS) in 1974, university institutes for professional studies (IUPs) in 1991 and more recently the vocational bachelor degree in $1999^{1}$ can be seen as a change in culture for the French universities (Box 1). The objectives were twofold. The first was to reduce a gap by providing skills required in specific sectors of the private labour demand. Second, the new partnership between higher education and employers created in these programmes was seen as an opportunity for graduates to be recruited more rapidly after graduation.

In the 1990s, the expansion of higher education was accompanied by a growing problem of graduate unemployment. Several longitudinal surveys have shown that the transition from higher education to employment has become more difficult and longer. If higher education graduates remained rather privileged compared to those from lower levels, their employment conditions became more difficult, with a strong increase in occupational downgrading and flexible jobs. In this context, our research aims to provide evidence of the success of vocational courses in the graduate labour market in France compared to academic courses. Using the latest Cereq surveys on school and university leavers, our data allow us to compare the patterns of graduates' transition to the labour market. The central question that will be addressed is: do university vocational courses tend to be associated with better labour market outcomes for graduates?

This article examines the implementation of vocational courses in the French 
higher education system. It then develops an empirical analysis of the labour market outcomes of vocational course graduates by focusing on the 'general' or 'academic' bachelor and the 'vocational' bachelor, created in 1999 in the frame- work of the Bologna Process. In order to take into account a potential selection bias due to the heterogeneity of students in the different courses, we elaborated a statistical evaluation method of labour market outcomes. Finally, some conclusions are drawn.

\section{Box 1. The French higher education system: a changing structure with the Bologna Process}

\section{First cycle}

Before the implementation of the Bologna Process, the classical university 'first cycle' lasted for two years and led to the Diplôme d'Etudes Universitaires Générales (DEUG) which was seen as the preparatory diploma for the second cycle. Students may alternatively enrol in university institutes of technology (IUT) to obtain the Diplôme Universitaire de Technologie (DUT), a two-year degree leading theoretically to technical employment. Another two-year technical programme in tertiary education, the Brevet de Technicien Supérieur (BTS), is offered by secondary schools. These two degrees can be followed by a one-year course leading to a diploma in specialised technology and now to the vocational bachelor degree. Students can also continue their studies in a general course at university (generally, at the level of the second year). The first cycle of training classes for elite schools -Classes Préparatoires aux Grandes Ecoles (CPGE)- also lasts for two years and prepares for the competitive entrance examinations for the elite schools (Grandes Ecoles).

\section{Licence / Bachelor degree}

The 'licence' is awarded after three years of studies in higher education (in humanities, science and technology, engineering, law and economics). It is now commonly considered as equivalent to a bachelor's degree in interna- tional terms and represents the first stage of the three-cycle 'licence/master/ doctorat' (LMD, 3-5-8) of European harmonised degrees. Students can choose a general or a vocational bachelor degree (licence professionnelle). The vocational bachelor degree (created in 1999) is employment-oriented, is prepared in one year and includes 12 to 16 weeks' work experience in a company. A total of 350 vocational bachelor courses were offered in the 2001 academic year. Bachelor degrees used to be followed by a one-year course leading to the 'Maîtrise' (4 years at universities).

\section{Master}

The master degree ${ }^{8}$ (vocational or research master degree) is awarded to students who have completed five years of study after the baccalaureate ${ }^{9}$. It was introduced in the academic year 2002-2003 and replaced the Diplôme d’Etudes Supérieures Spécialisées (DESS, vocational) and the Diplôme d'Etudes Approfondies (DEA, research). 


\section{The Implementation of Vocational Courses in the French Higher Education System}

Many developed countries have increased the number of vocational courses in higher education in order to propose an alternative to traditional university courses. As Grubb (2004, p. 10) noted, the non-university institutions that offer vocational education at tertiary level have, in many countries, been developed from older vocational institutions: polytechnics in Finland, Hogescholen in The Netherlands or further education colleges in the UK. In Germany, Fachhochschulen were created in 1971 as independent structures, but many have recently been renamed University of Applied Sciences in order to be considered at a level that is closer to universities. All the European countries have developed vocational training in higher education outside universities. However, an exception is the University Diploma (Diplomo Universitario), a short cycle university vocational degree created in 1991. Compared to these countries, the French system is characterised by an implementation of vocational courses at all levels of the higher education system, but with a very complex status hierarchy. First, most elite schools (Grandes Ecoles) can be considered as vocational institutions, but with very selective admission, higher spending per student, and a mix of vocational and academic training. Second, universities also offer vocational courses. Their recent growth has led to an increase in selective admission and spending per student. However, most students are still enrolled in general courses, which are characterised by open admission for the first years, lower spending per student and higher drop-out rates. Third, there are two-year technical and vocational post-baccalaureate programmes, the BTS and the DUT. BTS are offered in secondary schools, whereas $\mathrm{IUTs}^{2}$ belong to the university system, but benefit from strong autonomy. More specifically, the IUTs spend more per pupil than universities and have selective admission procedures, whereas universities must accept all students who hold the baccalauréat. Hence, teaching conditions are better and drop-out rates lower in IUTs than in general university courses.

Mass education has led to little selectivity for general courses at universities (Magnac \& Thesmar, 2002), whereas the vocational courses have systematically developed a policy of selective access. Although mass education did not necessarily lead to a drop in the quality of graduates, the lower entrance standards and the more problematic training conditions in general courses did generate stronger student attrition than in the vocational courses. It is important to note that this selectivity is the main difference with the vocational courses in secondary education (Vincens \& Chirache, 1992): while vocational courses are seen by students as the best way to obtain an employer-valued university degree, the latter are often considered as a second choice for those who have difficulties in 
the general courses. In the higher education system, the good reputation of vocational courses leads to confounding strategies: students who choose a long career begin with a vocational course and then pursue their studies in a general one. $74 \%$ of graduates of vocational degrees such as the DUT, which aims at a rapid integration in the labour market, continue their studies. The latest DGESADIUT survey shows that $50 \%$ continue their studies for more than one year. Vocationalism in higher education expresses different objectives depending on the country, field of studies, course and institution (Roemer, 1981; Hutmacher, 2002; Grubb, 2005).

\section{Supplying Qualified and Adequately Trained Workers}

Until the 1970s, the university's vocational role was to prepare students for the public service, teaching, research, medical professions and law. However, in the 1970s, the frequent and loud complaints of a future shortage of qualified people needed by the evolution of the French production system led public policies to develop vocational courses in higher education to supply qualified workers for different sectors of the economy in contrast to the academic and theoretical preparation of conventional university courses. Special importance was given to linking the trainees' interest and the skills required by the labour demand.

Vocational courses were seen as having a central role in improving the match between labour demand and supply, helping firms that had difficulties in recruiting qualified workers. As Lamoure (1987) noted, this implementation differed among the university levels of education. The creation of the University Institutes of Technology (IUT) in 1966 was a public answer to the needs of firms for intermediate qualified workers between blue collar workers and engineers. Students graduated with the DUT after two years of vocational training in higher education. In the 1970s, the level of qualifications was raised, priority being given to providing more qualified workers in some specific industries such as the services and hightech sectors. For example, the 'higher specialised studies diplomas' (DESS, five years after the baccalauréat) were created in 1974 to provide highly qualified workers. At the end of the 1980s, the creation of the University Institutes for Professional Studies (four years after the 'baccalauréat') was an answer to the lack of engineers and managers in some sectors. More recently, the 'vocational bach- elor' (Licence professionnelle), created in 1999, led to an intermediate qualification between the qualified technicians' diplomas and the engineering or senior man- agement diplomas. In order to be coherent with the three-cycle Licence/Master/ Doctorate framework of the Bologna Process, the vocational bachelor requires three years of study after the baccalaureat (Malan, 
2004). Students must have completed at least two years at university (Deug) or hold a two-year vocational degree (BTS or DUT). Moreover, the objective of the policy to supply adequately trained and qualified workers also responds to local and regional considerations. In order to be accredited by the Ministry of Education, a new vocational course has to show a clear partnership with employers at the local and regional level. In theory, at the local level, each degree must be created in response to a specific request from an employer or an occupational field to meet a skill shortage or marketplace demand. However, Maillard and Veneau (2006) showed that this was not always the deter- mining criterion for the accreditation of the vocational bachelor degree: $40 \%$ of the courses accredited in 2000 corresponded to the transformation of previous uni- versity or technological diplomas ${ }^{3}$.

\section{Increasing Partnerships between Universities and Employers}

French universities have been strongly criticised for the weakness of their links with employers, whilst elite schools have always privileged close relationships. As a result of the traditional independence of the academic system, universities were not generally aware that university-employer links may convey labour market information to students and influence job placements. So, one of the objectives of the vocational courses was to implement these relationships in different ways, imitating the elite school system (Grandes Ecoles). First, they generalised a compulsory scheme to give students a first work experience and contact with the labour market. In vocational courses, students generally spend a period in work placements each year. An academic tutor guides them in choosing the appropriate placement and remains in touch with them. As Dupeyrat (2002) noted, the objectives of these schemes are to facilitate student integration in the labour market, thereby securing valuable knowledge about the workplace, job requirements, and corporate culture; increase networking opportunities; sharpen career objectives; and become acquainted with the job market. In a local or regional labour market, students benefit by gaining an understanding of what employers are seeking when recruiting graduates. Hence, more informed career choices can be made.

Second, part of the vocational teaching can be designed in cooperation with employers to meet their needs and standards. In addition, employers may be involved in teaching programmes. For example, for the vocational bachelor, a rule imposes that a quarter of the programme is taught by non academic staff. However, Maillard and Veneau (2003) showed that this has led to a confounding effect. Although the aim was to benefit from the employers' and managers' corporate culture, the associated professors or temporary professors who were recruited were often members of the trade association and the employers unions.

Third, cooperation between universities and firms can be motivated by a search 
for extra funding to compensate for the higher training costs. Universities can obtain a share of the 'vocational training tax', which ranges from $0.25 \%$ to $1.5 \%$ of each enterprise's annual payroll. For most of these vocational courses, this kind of funding allows them to have better schooling conditions than in general courses.

Fourth, with the diversification and continuous creation of university degrees without suppressing the old degrees (Dubois, 1997), the supply of university courses is becoming more heterogeneous. The risk is that they may lose their visibility for the employers. This risk is lower for vocational courses: because of the cooperation between academic staff and firms, employers have a clearer view of the selection rules for admission to these courses ${ }^{4}$ and of their design. This may also assess students' productivity during their on-the-job training. In addition, vocational courses have national recognition and offer a path to further education. The entry selection based on both school performance and motivation or first labour experience may be viewed as a filter and a warranty that potential employees obtain the required skills and aptitudes. So, employers who recruit vocational course graduates gain by pre-screening potential employees and reducing training costs.

\section{An Empirical Analysis Using a Survey on Transition from Higher Education to the Labour Market}

During the recession of the 1990s, the expansion of higher education was accompanied by a growing problem of graduate unemployment. Many empirical studies have shown that the transition from higher education to employment has become more difficult and longer. In this section, we focus on research on three hypotheses.

First, vocational education reduces the qualification mismatch between graduate supply and employer demand. There is a large consensus in France that an increasing number of higher education graduates has difficulties in finding a job in relation with their qualifications (Forgeot \& Gautié, 1997; Giret \& Moullet, 2005). This leads to a growing process of professional downgrading on the labour market. As we have seen, one of the roles of university vocational training is to provide graduates who are more adequately trained for employers' requirements. So we may expect that it reduces professional downgrading.

Second, vocational education tends to be associated with higher pay. Most economists focus on the returns of an additional year of education, but some have compared the returns of academic and vocational qualifications (Psacharopoulos, 1987; Dearden et al., 2002). The main findings indicate that return on academic qualifications is generally higher than on vocational qualifications at an equivalent level. However, these results may strongly vary according to the education level, country and econometric methods employed. In France, most studies focused on secondary education and compared apprenticeship and other vocational tracks. 
The Margolis and Simonnet study (2006), which includes all educational levels, is the only piece of research that shows a positive effect on wages of vocational school in higher education. However, Margolis and Simonnet retain very aggregate educational levels and have no information about the graduates' field of study.

Third, vocational education tends to improve labour market information on job prospects.The previous section showed that its objective in French universities was to tighten institutional links between universities and employers. We may therefore expect that vocational education graduates will use these contacts more often than their counterparts in general courses in order to obtain their first job. Most of these contacts are the consequences of the job placement periods during their training, but also of all the forms of partnership with employers.

\section{Data}

This study uses data from the 'Generation 2001' survey carried out by Cereq. In spring 2004, Cereq questioned 15,000 young people who had left initial training in 2001, at all levels and in all training specialisations. This sample is representative of the 750,000 young people leaving the education system for the first time that year. The survey includes useful information on young people's characteristics (family's socio-economic status, age, highest degree obtained, highest degree attended, discipline, job during their study, work placement, ...) and work history from 2001 to 2004. Furthermore, for the first time, it includes a representative sample of vocational bachelor graduates. Here, we restrict the sample to the 789 respondents leaving higher education with a vocational bachelor degree and a general bachelor degree. They are representative of the 2,720 vocational bachelor graduates and 7,350 general bachelor graduates who left higher education in 2001. We will focus on the labour market outcomes in March 2004, which is the date of the interview.

Table I describes the main characteristics of the sample. The distribution of graduates by type of baccalaureate and by first course in higher education illustrates the complexity of the French education system, with a growing number of diplomas and institutions. However, we can observe strong differences in the educational track between general and vocational bachelor graduates. For $46 \%$ of the vocational bachelor graduates, specialisation began during the last year of secondary education with a vocational or technical baccalaureate. The year after, for their first access to higher education, three in four chose vocational training (a BTS or a DUT), while general bachelor graduates chose general training at university. The field of study also shows differences: students having specialised in science and technology are more frequently enrolled in vocational bachelor degrees than in general bachelor degrees. The gender structure is partially linked to the track orientation and to the field of study structure. Women, who generally 
prefer social sciences to technology, are less numerous in vocational courses than in general courses. In addition, Table I gives information about young people's geographical mobility in relation to their studies. It shows that vocational bachelor graduates are more mobile during their third year (prior to graduation): 20\% against $14 \%$ for the general bachelor graduates. Regional mobility may be explained by the fact that it is more difficult to find a vocational bachelor in a specific field of study in each region than a general bachelor degree. Finally, Table I shows that selection strongly differs between general and vocational courses: vocational course graduates are more frequently behind their age group than general course graduates (55\% versus $38 \%)^{5}$. This may be explained by the fact that vocational bachelor graduates chose a vocational or technical track in secondary education which can be longer than the general track. In addition, the criteria of selection between the academic and vocational track in higher education may also explain this difference: during the first years, the general courses at university are based on academic criteria, which is not the case in vocational courses. 
Table I. Sample characteristics

\begin{tabular}{|c|c|c|}
\hline & $\begin{array}{l}\text { Vocational } \\
\text { Bachelor }\end{array}$ & $\begin{array}{l}\text { General } \\
\text { Bachelor }\end{array}$ \\
\hline \multicolumn{3}{|l|}{ Type of baccalaureate } \\
\hline Vocational baccalaureate & $4 \%$ & $1 \%$ \\
\hline Technical baccalaureate & $42 \%$ & $12 \%$ \\
\hline General scientific baccalaureate & $35 \%$ & $35 \%$ \\
\hline General baccalaureate (human and social sciences) & $18 \%$ & $52 \%$ \\
\hline \multicolumn{3}{|l|}{ First course in higher education } \\
\hline Deug (first year of university) & $22 \%$ & $72 \%$ \\
\hline BTS & $38 \%$ & $7 \%$ \\
\hline DUT & $36 \%$ & $10 \%$ \\
\hline Other & $2 \%$ & $11 \%$ \\
\hline \multicolumn{3}{|l|}{ Geographic mobility during higher education } \\
\hline Regional Mobility & $27 \%$ & $20 \%$ \\
\hline \multicolumn{3}{|l|}{ Field of study } \\
\hline Services studies & $65 \%$ & $81 \%$ \\
\hline Industrial studies & $35 \%$ & $19 \%$ \\
\hline \multicolumn{3}{|l|}{ Gender } \\
\hline Men & $57 \%$ & $32 \%$ \\
\hline \multicolumn{3}{|l|}{ Family socio-economic status } \\
\hline Father high socio-economic status & $28 \%$ & $28 \%$ \\
\hline $\begin{array}{l}\text { Students who are behind their age-group when they } \\
\text { obtain their degree }\end{array}$ & $55 \%$ & $38 \%$ \\
\hline \multicolumn{3}{|l|}{ Age at entry in secondary education } \\
\hline Lower than the regular age (11) & $5 \%$ & $9 \%$ \\
\hline Regular age or over & $95 \%$ & $91 \%$ \\
\hline Sample size & 513 & 209 \\
\hline Representative population & 2378 & 7402 \\
\hline
\end{tabular}

Source : Cereq

\section{Method}

Our research attempts to show that labour market outcomes with a bachelor degree, which corresponds to three years of study in higher education, vary according to the type of education (general or vocational), even after accounting for students' heterogeneity. Since students must have completed at least two years of higher education and are admitted on the basis of their academic record or an interview, selection for the vocational bachelor programme is not random. Simple statistical results based on average outcome or simple regression fail to provide 
evidence of a positive effect of vocational courses (Ryan, 2003). This is because of the prior correlation between personal characteristics and the choice of a voca- tional bachelor degree which may partly explain the outcomes. This is why we apply a statistical method based on a non-parametric matching estimator which is used for the evaluation of active labour market programmes (Heckman, Ichimura \& Todd, 1997). The idea is to choose a control group (among the general bachelor graduates) to match the 'participant' group (the vocational bachelor graduate) on as many observable attributes as possible in order to neutralise the selection effect. Since the matching method requires a conditionally elaborated pairing procedure on personal characteristics (previous educational track, field of study . . .), a probit model is first used to calculate a propensity score, i.e. the conditional probability of receiving vocational training, given individual characteristics. Then, a Kernel estimator 6 is used to calculate an estimated gap. Finally, we estimate standard errors using a bootstrap procedure to obtain confidence intervals (Table II).

Table II. Labour market outcomes (vocational versus general bachelor)

\begin{tabular}{|c|c|c|}
\hline $\begin{array}{c}\text { Vocational } \\
\text { bachelor } \\
\text { graduates }\end{array}$ & $\begin{array}{c}\text { General } \\
\text { bachelor } \\
\text { graduates }\end{array}$ & Difference \\
\hline
\end{tabular}

\begin{tabular}{lcccc}
\hline $\begin{array}{l}\text { Professional downgrading } \\
\text { Observed difference (unmatched) }\end{array}$ & $16,6 \%$ & $25,4 \%$ & $-8,8$ & \\
$\begin{array}{l}\text { Average Tratement on the Treated } \\
\text { (ATT) }\end{array}$ & $16,6 \%$ & $36,3 \%$ & $-19,7$ & $0,09 * *$ \\
Wage gap & & & & \\
Observed difference (unmatched) & 1462 & 1199 & 263 euros & \\
& euros & euros & & \\
Average Tratement on the Treated & 1462 & 1290 & 171 euros & $30,52 * *$ \\
(ATT) & euros & euros & & \\
$\begin{array}{l}\text { Access to the job through university contacts } \\
\text { Observed difference (unmatched) }\end{array}$ & $34,9 \%$ & $29,3 \%$ & 5,5 & \\
Average Tratement on the Treated & $34,9 \%$ & $16,4 \%$ & 18,5 & $0,09 * *$ \\
(ATT) & & & & \\
\hline
\end{tabular}

Note : ** confidence interval $95 \%$

Table III shows the determinants of graduating with a vocational bachelor compared to a general bachelor, estimated by a probit model. The students' characteristics presented in Table I are introduced in the estimation 'all other things being 
equal'. As we have seen in Table I, the first course in higher education is key in explaining access to a vocational bachelor degree. Although paths exist between each degree, it is easier for BTS and DUT graduates to be selected for a vocational bachelor programme. Similarly, it is more difficult for students with a general baccalaureate to enter a vocational bachelor course. This shows the strength of the irreversibility of the choice of courses at the end of secondary education and in the first year of higher education, which predetermines the choice of entering the second cycle of higher education. However, the Table III results do not support evidence of a significant effect of other proxies of scholastic selection, which can be explained by the fact that these variables are strongly correlated with the previous education track in secondary education. Finally, we observe that graduates in industry and in exact sciences have better access to a vocational bachelor.

Results

\section{Professional owngrading}

The first dependent variable is professional downgrading, assessed by the statistical measure of Forgeot and Gautié (1997). Results are presented in Table II. The first line shows the observed (non matched) difference between vocational and general bachelor graduates. The average professional downgrading rate is $25.4 \%$ for general bachelor graduates and $16.6 \%$ for vocational bachelor graduates. The second line shows the results of the matching process when we compare vocational graduates with general graduates with similar characteristics. Matching strongly increases the downgrading rate for the general bachelors: whereas the unmatched difference was of 9 points, the match difference is about 18 percentage points. These results clearly show that vocational education graduates benefited from their training to find a better position on the labour market, especially when we compare with general bachelor students with the same characteristics. In addition, the results suggest that vocational bachelor students would have been more exposed to professional downgrading if they had not chosen a vocational degree because of some initial disadvantages (lower socio-economic status, less prestigious secondary education track). 
Table III. Probability of graduating with a vocational bachelor (rather than a general bachelor)

Coefficient Std Errors

\begin{tabular}{|c|c|c|}
\hline Constant & -0.25 & 0.24 \\
\hline \multicolumn{3}{|l|}{ Gender } \\
\hline Male & 0.08 & 0.14 \\
\hline \multicolumn{3}{|l|}{ Type of baccalaureate } \\
\hline Vocational baccalaureate & 0.05 & 0.75 \\
\hline Technical baccalaureate & Ref & Ref \\
\hline General baccalaureate (humanities or economics) & $-0.51^{* *}$ & 0.21 \\
\hline General baccalaureate (sciences) & -0.15 & 0.20 \\
\hline \multicolumn{3}{|l|}{ First course in higher education } \\
\hline Deug (first year of university) or non vocational training & Ref & Ref \\
\hline BTS & $1.43^{* * *}$ & 0.22 \\
\hline DUT & $1.98 * * *$ & 0.21 \\
\hline Other & 0.08 & 0.30 \\
\hline \multicolumn{3}{|l|}{ Geographic mobility during higher education } \\
\hline Regional Mobility & $0.30 *$ & 0.17 \\
\hline \multicolumn{3}{|l|}{ Field of study } \\
\hline Service studies & Ref & Ref \\
\hline Industrial studies & $1.02 * * *$ & 0.19 \\
\hline Summer job, odd jobs during school & -0.04 & 0,13 \\
\hline \multicolumn{3}{|l|}{ Age at entry in secondary education } \\
\hline Lower than the regular age (11) & 0.15 & 0.26 \\
\hline \multicolumn{3}{|l|}{ Students who are behind their age-group when they } \\
\hline obtain their degree & 0.04 & 0.15 \\
\hline Number of observations & 690 & \\
\hline Pseudo R2 & 0.43 & \\
\hline
\end{tabular}

Note: $* * * 1 \%, * * 5 \%, * 10 \%$, levels of significance.

\section{Wage Gap}

Three years after graduation, the question is to know whether a vocational bachelor degree increases graduates' monthly earnings. The unmatched results show that vocational graduates earn 1462 euros three years after graduation, whereas general graduates earn 1199 euros. The matching procedure reduces the wage gap from 263 to 170 euros. However, the wage premium for vocational graduates is still positive when controlling for student characteristics. This is congruent with the previous result: the better labour market outcomes of vocational bachelors are due to the human capital, the 'know how' they acquire during their studies. However, the smaller difference between the unmatched and the matched differences suggests that the characteristics of vocational students are less unfavourable in explaining the wage gap than in explaining the professional downgrading. This may 
be because the specialisation of vocational bachelors corresponds more frequently with occupations in industrial sectors where degrees are generally more valued by employers.

\section{Access to Jobs}

Table II shows that $34.9 \%$ of vocational bachelor graduates accessed their job using university-based contacts compared to $29.3 \%$ of general bachelor graduates. The matched results show that only $16.4 \%$ of general bachelor graduates used this institutional network to find a job. So, the difference increases in favour of vocational bachelors graduates. This is not surprising because a work placement period is not compulsory in general bachelor training. In addition, vocational bachelor graduates are more private sector-oriented, whereas general bachelor graduates may search for jobs in the public sector where entrance is regulated by competitive exams.

\section{Conclusion}

One of the great policy questions of the last decades in France was how to increase young people's skills to meet employers' recruitment needs. During this period, universities which witnessed a dramatic growth in enrolment were strongly criticised. With the increase in graduate unemployment, detractors often disparaged universities, described as cut off from society in their 'ivory towers'. However, since the 1970s, universities have changed their courses to face the changing economy and the demands of students and employers. The dramatic increase in students enrolled in vocational courses is proof of this new strategy endorsed by the different Ministers of Education.

On the basis of the Cereq survey of graduates, our analysis allowed us to compare the main school-to-work transition patterns of vocational course and general course graduates. Furthermore, for the first time, this database provides a representative sample of graduates of the new vocational bachelor and allows us to compare the same degree obtained in a general or a vocational course. Our results show that vocational bachelor training facilitates transition from university to the labour market, even when controlling for student characteristics by statistical methods. As expected, vocational training at university level helped to reduce the professional downgrading and increase the wages of university leavers three years after graduation. In addition, the vocational bachelor graduates benefited from the stronger institutional links between universities and employers to find their job.

But several caveats are worth mentioning. One pertains to the fact that our database only includes those graduates who decided to leave higher education, whereas it would obviously be desirable to have information on the trajectories of 
those who continue their studies. Most students consider the general bachelor as a first degree towards a master's, except for those who plan to join the public administration where access is through a competitive exam ${ }^{7}$. Hence, one may argue that those who leave university with a general bachelor represent a selection of graduates with specific characteristics compared to those who enrol in a master degree. However, the number of general bachelor graduates who decide to enter the labour market is not negligible and is likely to increase if the target of $50 \%$ of an age class reaching the bachelor level is attained. The latest Cereq survey shows that only $30 \%$ of university leavers at the bachelor level held a vocational bachelor degree in 2004 (Calmand \& Hallier, 2008), although the number of vocational bachelor graduates had strongly risen since 2001: in 2004, 1,000 vocational bachelor courses were proposed to 26, 900 students.

Secondly, wage gaps or professional downgrading may change during graduates' career. General course graduates may reach the same wage conditions during the first years of active life when they have better information about their job prospects. However, we observe the same wage gap in first jobs obtained after graduation and in jobs obtained three years later. Thirdly, despite accounting for wage and employment consequences, we do not assess non pecuniary job conditions. For example, general course graduates may choose careers in the public sector where the wages are generally lower but job satisfaction may be higher. However, if we look at the opinion of graduates about their skills mismatch three years after graduation, 31\% of vocational bachelor graduates state that they are employed below their skill level versus $40 \%$ of general bachelor graduates.

Jean-François Giret, IREDU, CNRS, Université de Bourgogne, bureau 115, Pôle AAFE-Esplanade Erasme, BP 26513-21065 Dijon Cédex, France e-mail: jean-francois.giret@u-bourgogne.fr, http://iredu.u-bourgogne.fr/equipe/enseignants--chercheurs/77-jean-francoisgiret.html

\section{NOTES}

1. Institut Universitaires de Technologie, Maîtrise d'Informatique appliquée à la Gestion, Diplôme d'Etudes Supérieures Spécialisées, Institut Universitaire Professionnalisé.

2. This is the main difference between the Sections de Techniciens Supérieurs which confer the Brevet de Technicien Supérieur and tertiary institutes operated by secondary schools (lycées).

3. It is interesting to note that little evidence of an 'academics drift' can be found in France. As Jallade (1992) mentioned, the non-university sector resisted academic drift and the creation of courses and degrees in the French univer- sities 
may be viewed as a vocational drift. The creation of the vocational licence clearly seems to follow this logic.

4. Employers may be members of the selection committee for entry to the vocational course.

5. Our only indicator is students who are behind their age-group (based on the theoretical age of preparation for the terminal qualification) which is very imprecise and could be criticised. Unfortunately, we do not have any information on student evaluation or test during secondary education or the first years of tertiary education. However, the information on age and the second- ary education baccalauréat, which is very discriminating in France, can be considered as a proxy of school ability.

6. The estimation is carried out using psmatch2 in Stata 8.0 (Leuven \& Sianesi, 2003).

7. According to the French Ministry of Education, in 2005, two thirds of general bachelor graduates went on to study for a master degree and 12\% enrolled in the University Teacher-Training Institutes (IUFM: Institut de Formation des Maîtres). In comparison, about $17 \%$ of graduates with a vocational bachelor continued their studies.

8. The French elite schools (Grandes Ecoles) are not presented here. Most can deliver a master's degree.

9. The ECTS allows students to transfer credit units for academic study modules between higher education institutions in different European countries. An academic year corresponds to 60 credits. The master degrees correspond to 300 ECTS after the baccalaureate or 120 ECTS after the licence. Preparation for the terminal qualification is very imprecise and could be criticised. We do not have any information about student evaluation or test during secondary education or the first years of tertiary education. However, the information on age and the secondary education baccalaureate can be considered as a proxy of school ability.

\section{REFERENCES}

Calmand, J. \& Hallier, P. (2008) Être diplômé de l'enseignement supérieur, un atout pour entrer dans la vie active, Bref Cereq, ${ }^{\circ} 253$.

Dearden, L., Mc Intosh, S., Myck, M. \& Vignoles, A. (2002) The returns to academic and vocational qualifications in Britain, Bulletin of Economic Research, 54, pp. 249-274.

Dubois, P. (1997) Université: croissance et diversité de l’offre de formation, Formation Emploi, 58, pp. 10-14.

Dupeyrat, G. (2002) Les filières professionnalisées de l'enseignement supérieur, Rapport à Monsieur le Ministre délégué à l'enseignement professionnel. Eicher, J. C. (1999) Jusqu'où faut-il professionnaliser? Sociétal, 26, 
pp. 79-83.

Giret, J-F \& Moullet, S. (2005) L’adéquation formation-emploi après les filières

professionnelles de l'enseignement supérieur, in: J. F. Giret, A. Lopez \& J. Rose (Eds) Des formations pour quels emplois? (Paris, La Découverte, Collection Recherche) pp. 111-125.

Grubb, N. (2004) Alternatives to universities revisited, OCDE, Education Evalua-

tion Analysis, 46.

Grubb, N. (2005) Vocationalism in higher education: the triumph of education gospel, The Journal of Higher Education, 76, pp. 1-25.

Forgeot, G. \& Gautié, J. (1997) Insertion professionnelle des jeunes et processus de déclassement, Economie et Statistique, 304-305, pp. 53-74.

Heckman, J. J., Ichimura, I. \& Todd, P. (1997) Matching as an econometric evaluation estimator, Review of Economic Studies, 65, pp. 261-294.

Hutmacher, W. (2002) L'université et les enjeux de la professionnalisation, Politiques d'éducation et de formation. Analyses et comparaisons internationales. Jallade, J. P. (1992) Undergraduate higher education in Europe: towards a comparative perspective, European Journal of Education, 27, pp. 121-144

Lamoure-Rontopoulo, J. (1987) Professionnalisation des enseignements, Projet, 205, pp. 31-38.

Leuven, E. \& Sianesi, B. (2003) PSMATCH2: Stata module to perform full Mahalanobis and propensity score matching, common support graphing, and covariate imbalance testing, Statistical Software Components S432001, Boston College Department of Economics, revised 28.

Magnac, T. \& Thesmar, D. (2002) Analyse économique des politiques éducatives: l'augmentation de la scolarisation en France de 1982 à 1993, 65, Annales d'Economie et Statistiques, pp. 1-34.

Maillard, D. \& Veneau, P. (2003) Les licences professionnelles: quelle acception de la professionnalisation à l'université?, Relief, 5, Céreq.

Maillard, D. \& Veneau, P. (2006) Les licences professionnelles: formes et sens pluriels de la professionnalité à l'université, Sociétés Contemporaines, 62, pp. 49-68.

Malan, T. (2004) Implementing the Bologna Process in France, European Journal of Education, 39, pp. 289-297.

Margolis, D. \& Simonnet, V. (2006) Filières éducatives, réseaux et réussite professionnelle, Economie et prévision, 164, pp. 113-129.

Psacharopoulos G. (1987) To vocationalize or not to vocationalize: that is the curriculum question, International Review of Education, 33, pp. 187-211.

Roemer R. E. (1981) Vocationalism in higher education: explanations from social 
theory, The Review of Higher Education, 4, pp. 23-46.

Ryan P. (2003) Evaluating vocationalism, European Journal of Education, 38, pp. 147-162.

Vincens J. \& Chirache S. (1992) Rapport de la Commission 'Professionnalisation des Enseignements Supérieurs’, Haut Comité Éducation Emploi Économie. 